\title{
The Russian Revolution and the Instrumentalization of Death
}

\author{
Svetlana Malysheva
}

A new way of dealing with death was to play a significant role in the construction of Soviet society. As aptly noted by Jean Baudrillard, the separation of the living and the dead is the first stage of social hierarchy building and a social discrimination tool. Control over death and the dead is the first and crucial condition of social control over the living. ${ }^{1}$ Once in power, the Bolsheviks made ample use of their right to classify people as living or dead-not only through physical violence and elimination of "enemies," but also through symbolic acts of signification. "Dead and old" vs "living and young": such were the two poles between which new social hierarchies during the early years of Soviet power were built. ${ }^{2}$ In the 1920s, gerontophobia and the cult of youth were fostered in Soviet society. Along with desacralization of death and the debunking of the cult of the dead, Bolsheviks were fulfilling an important revolutionary function of breaking bonds between generations, destroying traditions and social ties, without which the construction of the new Soviet structure of social relationships would hardly be possible. ${ }^{3}$ The prevalence of cynical, pragmatist gerontophobia in the youth cult of the 1920s reflected the fear of being on the lower rungs of the social ladder.

During the first two decades after the revolution, the Bolsheviks instrumentalized death and death culture for the construction of new social hierarchies. The peculiarity of this instrumentalization manifested itself in a combination of two seemingly opposite but interrelated trends: a cynical and pragmatic use of death on the one hand, and a high degree of its symbolization on the other. A number of factors was behind this ambivalence, including, first, the biosocial and biopolitical utopias of the late nineteenth and early twentieth centuries that envisaged overcoming old age and death by transforming the philosophical, religious, and moral issues associated with death into scientific and technological problems, and substituting the concept of the "immortality of protoplasm" for the idea of the immortality of

The author sincerely thanks the Slavic Review anonymous reviewer and editor for their comments and suggestions. This article represents part of the author's research within the framework of the project "The Red Thanatos: The History and Culture of Death in Soviet Russia (1917-1991)" sponsored by the Fritz Thyssen Foundation (Fritz Thyssen Stiftung, Projekt "Der rote Thanatos: Geschichte und Kultur des Todes in Sowjetrussland, 1917-1991”)/Az.20.15.0.045).

1. Jean Baudrillard, Symbolic Exchange and Death, trans. Iain Hamilton Grant (London, 1993), 129-30.

2. This opposition was also reflected in fiction-cf. Violetta Gudkova, Rozhdenie sovetskikh siuzhetov: Tipologiia otechestvennoi dramy 1920-kh-nachala 1930-kh godov (Moscow, 2008), 221-45.

3. For the early Soviet culture's gerontophobia, cf. Mikhail Vaiskopf, Pisatel' Stalin (Moscow, 2001), 293-295, 327-330, 335; Gudkova, Rozhdenie sovetskikh siuzhetov, 173-95. 
the soul..$^{4}$ Second, this ambivalence was rooted in the subculture of Russian radical revolutionaries who glorified terrorists as "heroes," romanticized "heroic suicide," and endorsed murder and suicide as acceptable means to achieve the common good, thus distorting the traditional sacred status of death. ${ }^{5}$ Finally, the First World War went a long way to further desacralization of death. However, given that in the absence of the soul every individual faced the prospect of traceless and definitive disappearance, a necessity was felt to justify both life and death as expediential for the common good and for the future communist society, and to integrate it into the cultural symbolic system of the "cult of the fallen."

The Bolsheviks used and tried to normalize under "conditions of peace" the two sides of death culture that had taken shape under the extreme conditions of the First World War: the cult of fallen military officers and soldiers (which was emerging but had no time to fully take shape before the start of the revolution), and the frontline trend towards minimizing and secularizing funeral rituals and displays of grief. ${ }^{6}$ The funerals of the victims of revolution on the Field of Mars in St. Petersburg on March 23, 1917, however, already represented an attempt to instrumentalize both trends: the ceremony combined the pomp and solemnity of revolutionary ritual with the minimalist, de-individualizing method of burial in mass graves. ${ }^{7}$ Later on the Bolsheviks differentiated burial rituals, using different types of funerals as clear markers of social status. Most probably, this was not a circumspect and conceptualized policy, rather it took shape spontaneously and situationally in practice, borrowing patterns from foreign cultures and inventing new ones.

The cult of fallen soldiers from the World War I era rendered a basis for the Bolshevik cult of fallen "red leaders and heroes," used as a tool of the Soviet elite's hierarchization. It is noteworthy that gerontophobia did not affect the revolutionary intergenerational ties and the revolutionaries themselves, particularly their leaders. In Soviet society of the 1920s, the word "old" only had positive connotations in the revolutionary context: for example, of the "Society of Old Bolsheviks" (1922-1935) and the "Old Bolshevik" almanac

4. For biosocial and biopolitical utopias, see: Boris Groys, Michael Hagemeister, and Anne von der Heiden, eds., Die Neue Menschheit: Biopolitische Utopien in Russland zu Beginn des 20. Jahrhunderts, trans. Dagmar Kassek (Frankfurt am Main, 2005). The "immortality of protoplasm" is discussed by Aleksandr Bogdanov in "Ocherki organizatsionnoi nauki: Raskhozhdenie i skhozhdenie form," Proletarskaia kul'tura, no. 15-16 (1920): 28.

5. See Marina Mogil'ner, Mifologiia "podpol'nogo cheloveka": Radikal'nyi mikrokosm $v$ Rossii nachala XX veka kak predmet semioticheskogo analiza (Moscow, 1999); Oleg Budnitskii, Terrorizm v rossiiskom osvoboditel'nom dvizhenii: Ideologiia, etika, psikhologiia (vtoraia polovina XIX-nachalo XX v.) (Moscow, 2000); Susan K. Morissey, Suicide and the Body Politic in Imperial Russia (Cambridge, 2006).

6. For details see Svetlana Malysheva, "Bereavement and Mourning (Russian Empire)," trans. Trevor Goronwy, in Ute Daniel, Peter Gatrell, Oliver Janz, Heather Jones, Jennifer Keene, Alan Kramer, and Bill Nasson, eds., 1914-1918-Online: International Encyclopedia of the First World War (Berlin, 2014), at http://encyclopedia.1914-1918-online.net/pdf/19141918-Online-bereavement_and_mourning_russian_empire-2014-10-08.pdf (last accessed June 13, 2017).

7. See: Marina Chertilina, "Pokhorony zhertv Fevral'skoi revoliutsii v Petrograde 23 marta 1917 g. v fotodokumentakh RGAKFD,” Otechestvennye arkhivy, no. 1 (2011): 45-52. 
that it published. Revolutionary "genealogical" intergenerational ties were fostered, and the revolutionaries themselves were a priori placed on top tiers of the new social pyramid. Rather than being socially marginalized, dead (and old) red leaders and heroes even crowned the hierarchy: "The shadows of fallen comrades remain ahead of our ranks and lead us to victory," a revolutionary author wrote in $1918 .{ }^{8}$ By not leaving the ranks of the living, the fallen comrades seemed not fully dead. ${ }^{9}$ Even the graves of fallen comrades were described as "living graves." 10 Descriptions of red leaders and heroes' death always fit into the matrix of "heroic self-sacrificing death" and thereby normalized, as it were, the completion of their revolutionary biography: "He was killed while on duty . . . Comrade Uritskii, a hero and a great toiler of the revolution, just could not have died otherwise."11 Moreover, neither the circumstances of a revolutionary's death, nor their last diagnosis mattered when their death was placed within a "heroic" discourse. ${ }^{12}$

Another reason why heroic, sacrificial death played an important role in the formation of the Soviet concept of death was that it raised a hero and leader above the crowd, as well as above the frailty of life and above non-existence. Moreover, it provided an answer to the nagging question that the propaganda of atheism inevitably raised: if there is no soul and no posthumous reward, and everything ends with one's physical death, then what is the point of it all? Heroes and leaders acquired a welcome immortality within the framework of the cult of "our dead," that is, the fallen ones. When speaking about the immortality of their heroes and leaders, the Bolsheviks often appealed to the images of saints and Christ and used the word soul, especially when it came to reflecting upon the death of Vladimir Lenin. ${ }^{13}$ Besides the immortality of his ideas, Lenin's immortality could be conceived of as his almost physical incarnation in every communist. ${ }^{14}$ Analyzing the religious roots of the cult of

8. P. Smidovich, “Zhivaia mogila,” Znamia revoliutsii, September 22, 1918, 1.

9. Two days after the murder of Moisei Volodarskii, Anatolii Lunacharskii described the concept of immortality: "I saw Volodarskii's corpse today, and it did not make the impression of a corpse on me. (...) When such people die, they rise from the grave like warriors, like giants. Such victims never remain in their graves." Anatolii Lunacharskii, quoted in, "V. Volodarskii (1891-1918)," Kommunisticheskii Internatsional, no. 3 (1919): 349, 352.

10. See Smidovich, “Zhivaia mogila,” 1.

11. "Biografiia tov. Uritskogo (K godovshchine so dnia smerti)," Kommunisticheskii Internatsional, no. 4 (1919): 550.

12. For example, when Vladimir Lenin died after a long and severe illness, Pravda thus characterized his passing on January 24, 1924: "The proletarian leader was struck down by death amidst the fire of a severe fight (. . .).” See: V. Kolarov, "U mogily tov. Lenina," in M. Rafes, M. Model', and A. Yablon'skii, eds., U velikoi mogily (Moscow, 1924), 36.

13. For instance, Lenin's death was described as special: "the physical death of Vladimir Lenin is a special kind of death that took the leader's body from the global family of workers but only hardened the unquenchable spirit of Leninism (...)." See A. Zorov, "Chernoe i krasnoe," in Trud, January 24, 1924, as cited in U velikoi mogily, 84. The word "soul" was used in no uncertain terms to characterize Lenin's immortality: "What cannot die is his best essence, his true and living soul; Lenin the immortal cannot die." See A. Ioffe, "V venok Leninu," in Pravda, January 26, 1924, as cited in U velikoi mogily, 186.

14. "Every member of our party is a bit of Lenin. Our whole communist family is a collective incarnation of Lenin.” See "Vozzvanie TsK RKP K partii. Ko vsem trudiashchimsia ot 22 ianvaria," in U velikoi mogily, 9. 
Lenin and red heroes, Nina Tumarkin correctly described this cult as a secular religion. ${ }^{15}$ Indeed, Bolshevik ideas about the social immortality of their leaders and heroes clearly showed religious traits.

This never-articulated division into "ordinary" people, who were not supposed to have souls, and "heroes and leaders," whose ecstatic self-sacrifice likened them to immortals and who transubstantiated into the eternal spirit of communism, partly explains a discrimination concerning the burial of the dead that existed during the first decade of Soviet power. To a certain extent, the two trends within Soviet death culture concerned two different categories of people: pathos was for leaders and revolutionaries, pragmatism was for ordinary citizens. True, pathos and pragmatism did not exist in pure form but often intertwined. The cult of the dead, however, was formed by the Bolsheviks almost exclusively as a cult of leaders and heroes.

This cult was reinforced by hierarchization of burial sites. Members of the top-bracket Soviet elite were separated geographically and symbolically from its lower brackets and, of course, from the rank-and-file citizens. Soon after the revolution, the Red Square in Moscow, as Russia's main square, became the most prestigious elite cemetery. Being laid to rest near the Kremlin wall beside the Lenin Mausoleum was like being buried ad sanctos (near a church, where the graves of saints and martyrs were) in the Middle Ages. This was an honor awarded only to leaders and heroes of high rank, such as the leaders of the Communist Party and Soviet government. Moreover, the way one was buried also differed, depending on the status of the deceased. Prior to the opening of the Moscow crematorium (1927), the high status of a deceased person was signified by them being buried in a separate grave. By then, only Iakov Sverdlov (1919), Mikhail Frunze (1925), and Feliks Dzerzhinskii (1926) were buried alone. Other heroes and outstanding figures (more than 300 people in all since 1917) were buried in the so-called "communal," or mass graves. After the opening of the Moscow crematorium and until 1946, all dead leaders and heroes to be buried in the Kremlin wall were cremated. ${ }^{16}$ The high prestige of the place of burial made up for the low prestige of the method (cremation). Between 1946 and 1985, separate land burial sites near the wall were granted to another nine most outstanding party and state leaders (including Joseph Stalin, whose body rested in the Mausoleum between 1953 and 1961). Despite the propaganda of cremation, by land-burying certain persons near the Kremlin, the Bolsheviks de facto recognized land burial (with which the Orthodox Christian tradition associated the possibility of resurrection) to be more prestigious. This hierarchy, however, was never admitted vis-à-vis the people, with all Kremlin burials being described uniformly as ones "on Red Square near the Kremlin wall."

As the hierarchization of Soviet society deepened, privileged burial sites were inaugurated for less outstanding comrades, such as the Novodevichy

15. Nina Tumarkin, Lenin Lives! The Lenin Cult in Soviet Russia (Cambridge, Mass., 1983), $1-23$.

16. Between 1925 and 1984, ashes of 115 deceased persons were immured in the Kremlin wall. See "Nekropol' u Kremlevskoi steny," at http://ru.wikipedia.org/wiki/ Некрополь_у_Кремлевской_стены (last accessed June 13, 2017). Four persons died abroad and were cremated there before the Moscow Crematorium opened. 
Cemetery in Moscow, according to the decision of the Central Executive Committee of the USSR in 1927. In Leningrad, such designated sites were the Field of Mars and the St. Aleksandr Nevskii Monastery. From Moscow and Leningrad, the hierarchy of cemeteries was transposed to the provinces and reproduced in almost all major cities of the USSR. During the first decades of Soviet power, special "communist plots" were created in ordinary cemeteries. They were named after the communist plot in the cemetery of the St. Aleksandr Nevskii Monastery, which came into being in 1919. Among those buried there in 1920s and 1930s were participants in the 1919 defense of Petrograd during the Civil War, victims of the 1921 Kronstadt rebellion, revolutionaries, party functionaries, military officers, scholars, artists, communists, and atheists. In the early years, however, there was no rigid hierarchy, with ordinary people, even believers, being occasionally buried here. Communist plots appeared in other cemeteries of Leningrad (Bolsheokhtinskoe Cemetery), Moscow (Vagan'kovskoe Cemetery) and other cities throughout the country (such as the Botkinskoe Cemetery in Tashkent). Since the late 1930s and after World War II, communist plots were not marked anymore, but the need to allocate the best sites and parts of cemeteries for the burial of prominent Soviet people was habitually cited in many documents of the 1930-1970s. The status of the necropolis, the place in the cemetery or in the columbarium where one was laid to rest, became a very clear sign of one's place in the hierarchy.

Ordinary citizens and rank-and-file Communist Party members in the 1920s were the target group of propaganda promoting minimization and rationalization of burial practices and rituals, economical mass graves, and cremation. This propaganda vigorously promoted secularization of death as an aspect of everyday life, and disavowed the worship of ancestors, instilling cynical pragmatism with regard to human remains and old cemeteries instead. Old cemeteries were leveled for parks, stadiums, warehouses, and industrial areas, while the tombstones and fences were recycled for the needs of construction and industry. A special role in this process of desacralization of death was assigned to the promotion of cremation, widely propagated since the early 1920s. Given the high mortality in the country during this time, the poor performance of funeral agencies, and the acute shortage of land in city cemeteries, cremation was a solution, but it was intended to serve not only practical needs. Its main purpose was to help instill in the citizens of Soviet Russia an atheistic attitude towards death and a pragmatic and unemotional approach to the fate of their remains. For example, the director of the SanitaryHygienic Institute, Professor Petr N. Diatroptov, wrote: "The human corpse is garbage that must be destroyed." ${ }^{17}$ In the post-revolutionary years, death was consistently deprived of sacredness and intimacy, and turned instead into a laboratory experience or a show. ${ }^{18}$

17. “Nasha anketa o krematsii,” Kommunal'noe Khoziaistvo, no. 11-12 (1927): 30.

18. For instance, Sunday guided tours through the Moscow crematorium built in 1927 were offered to the working masses, and the organizers made a point of "having corpses cremated on Sundays, too, for the participants of guided tours to have an opportunity to watch corpse burning process live." See S. Nekrasov, "Pervyi Moskovskii krematorii," Kommunal'noe Khoziaistvo, no. 23-24 (1927): 28. 
Although in December 1918 the Bolsheviks issued a decree abolishing the class hierarchy of funerals and burial places that existed before the revolution and declaring "equal funerals" for all citizens, they themselves quickly abandoned this cemetery egalitarianism. ${ }^{19}$ Grave spaces and burials were free only for "workers"; the rest had to pay. From November 1921 on, all burials and grave spaces had again to be paid for regardless of social class. The cheapest funeral cost an average worker's monthly salary while the most expensive cost an annual salary. ${ }^{20}$

Mass graves were the cheapest and most widespread. ${ }^{21}$ Mass graves reflected, as it were, the Bolshevik ideas of "communization," with people living in communes and communal flats. They became a normality-so much so that in 1923 the director of the Transcaucasian Railway even proposed reusable coffins to be offered for hire. ${ }^{22}$ In fact, reusable coffins were not uncommon in 1918-1919. ${ }^{23}$

Differential rates for different social classes were soon introduced, clearly designating the deceased person's position in the nascent Soviet social hierarchy, emphasizing class discrimination. As early as 1927, it was suggested that the cremation fee for non-workers should be twice as high as that for the liberal professions and four times higher than those for industrial workers and civil servants. ${ }^{24}$ In February 1929, the Moscow City Council ordered that burial in a cemetery or cremation should cost 1 ruble for workers and employees, 5 rubles for the liberal professions, and 20 rubles for all other categories. ${ }^{25}$ As the hierarchization and differentiation of Soviet society progressed, this tariff hierarchy grew more complicated and detailed, too. In 1931, the rates were itemized in detail for four categories with subcategories: three subcategories of manual and office workers, depending on their earnings-3 to 15 rubles; artisans working by themselves-15 rubles; artisans employing wage

19. "Dekret SNK ot 7 dekabria 1918 g. “O kladbishchakh i pokhoronakh,” in Dekrety Sovetskoi vlasti, vol. 4 (Moscow, 1968), 163-164.

20. L.V. Borisova, Trudovye otnosheniia v Sovetskoi Rossii (1918-1924 gg.) (Moscow, 2006), 168.

21. In some of Moscow cemeteries in 1923/24 they accounted for over a third of all graves (V. Fedynskii, "Kladbishchenskii krizis v Moskve i krematsiia,” Kommunal'noe Khoziaistvo, no. 9-10 (1926): 24. In the provinces, sometimes even more so: in Kazan' between 1922 and 1925, 38\%-68\% of all the dead were buried in mass graves. See Natsional'nyi arkhiv Respubliki Tatarstan (NART), fond (f.) R-1130, opis' (op.) 1, delo (d.) 333 (mesiachnye finansovye otchety po ekspluatatsii kladbishch i kvartir, 1925-1926), list (1.) 47; f. R-1803, op. 1, d. 235 (mesiachnye otchety o deiatel'nosti Arskogo kladbishcha, 1922-1923), 1l. 30, 35, 46, 137, 145.

22. Tainy natsional'noi politiki TsK RKP: Chetvertoe soveshchanie TsK RKP s otvetstvennymi rabotnikami natsional'nykh respublik $i$ oblastei v Moskve 9-12 iiunia 1923 g. Stenograficheskii otchet (Moscow, 1992), 149. 205.

23. See R. Donskoi, “Ot Moskvy do Berlina v 1920 g.,” Arkhiv russkoi revoliutsii 1 (1921):

24. See L. Klempner and S. Nekrasov, “Pervyi krematorii v g. Moskve,” Kommunal'noe Khoziaistvo, no. 1-2 (1927): 25.

25. Gvido Bartel', "Znachenie zheleznodorozhnogo transporta v dele razvitiia krematsii,” Kommunal'noe Khoziaistvo, no. 3-4 (1929): 26. 
labor-25 rubles; professionals-25 rubles; non-workers-35 rubles. ${ }^{26}$ And if for industrial workers, the fee depended on their earnings, for other classes, the income (or lack thereof) did not matter. Burial tariffs differentiated on the basis of class remained in force until the Soviet Constitution of 1936 declared that the exploiting classes no longer existed in the USSR. The distribution policy with regard to cemetery space (communist plots, honorable burial sites) also differentiated and hierarchized the deceased according to their class and social significance.

The dualism of the death culture imposed by the authorities was perceived and reinterpreted by the population in different ways. Most people sought to avoid what they thought was excessive pragmatism when it came to themselves and their loved ones. Cremation, for example, was not widespread in these years. The majority of those cremated in Moscow crematoriums were so-called "ex officio" cases (stillborn infants, bodies subjected to forensic autopsy, lonely unconnected persons). Cremation was opted for by relatives of only $4.3 \%$ of all deceased Muscovites in 1928, 5.8\% in 1929, 7.8\% in 1930, and $7.6 \%$ in $1931 .{ }^{27}$ Most of the time, relatives of the deceased tried to avoid them being buried in mass graves.

Still, the efforts to impose pragmatism and indifference with regard to death was not unsuccessful. It eroded the very belief in the sacredness of old cemeteries and graves, new holy places included. To the Bolshevik leadership's surprise and dismay, Soviet citizens indifferently ignored the statesponsored red cult of the dead leaders and heroes well into the 1930s. Graves of Red Army soldiers and Civil War heroes were in terrible disrepair, some of them destroyed. Since 1928, their protection was repeatedly discussed by the Presidium of the USSR Central Executive Committee, whose members tried to shift this task to public organizations ${ }^{28}$ Even though it did set up a Commission for the Protection of Civil War and Red Army Monuments (1934-1937), this body was unable to overcome indifference and formalism in attitudes towards "red graves" among either high-ranking party and government functionaries or public organizations and a significant part of the population, who had been taught indifference to the fate of graves and graveyards for many years. ${ }^{29}$

In fact, ordinary Soviet citizens actively borrowed and transferred elements of the cultural symbolic system, including the red heroes and leaders cult, to private funerary culture, embedding the deceased in the new Soviet hierarchy. For example, heroic death became a trope widely used in ordinary citizens' obituaries and epitaphs. ${ }^{30}$ As early as the 1920 s-30s, Soviet symbols

26. See Gvido Bartel', “Razvitie krematsii v Moskve v 1930-1931 gg.,” Kommunal'noe Khoziaistvo, no. 6 (1932): 63.

27. Gvido Bartel', "Rabota Moskovskogo krematoriia,” Kommunal'noe Khoziaistvo, no. 19-20 (1929): 34; Bartel', "Razvitie krematsii v Moskve v 1930-1931 gg.," 60.

28. Gosudarstvennyi arkhiv Rossiiskoi Federatsii (GARF), f. R-3316, op. 52, d.19, 11. 16, 35, 37 (perepiska o sostave i rabote Komissii pri Prezidiume TsIK po okhrane pamiatnikov grazhdanskoi voiny i Krasnoi Armii, 1934).

29. Ibid., 11. 1, 30, 35.

30. Thus, the inscription on the tomb of the worker Seliverst Glazunov, who died of cardiosclerosis aged 54 in 1928 and was buried at the Novodevichy Cemetery, described his death as that of "a fallen fighter, a soldier of the revolution who died in the line of duty fighting for the workers' and peasants' struggle for socialism.” 
were widely used on gravestones irrespective of the dead person's (or their family's) belonging to some rank of the Soviet elite or another. No matter the degree of communist indoctrination, communist symbols became part of the emerging Soviet traditions, including a hybrid Soviet cult of ancestors. Its hybridity manifested, for example, in adapting and blending symbols, with tombstones often having the traditional form of a Christian chapel, but topped by a five-pointed star instead of a cross, or by tombstone inscriptions bearing traditional Christian epitaph texts accompanied by indications of the deceased person's Communist Party membership and Soviet social merit. The Soviet character of private funerary culture became a hybrid, as did the identity of the great majority of the people who described and conceived of themselves as Soviet. It was in a perfectly coherent and consistent way that their death and funerary practices combined elements of Soviet culture and ideology, religious and everyday beliefs, as well as values and rituals.

As a result, by the end of the 1930s, Soviet death culture was a hybrid phenomenon that intricately combined elements of a vigorous religious tradition with splashes of Soviet "innovations." This barely shook or changed, however, the Bolshevik practice of instrumentalizing death that was designed to serve the purpose of building new social hierarchies. By borrowing and modifying Soviet elements, people objectively contributed to the establishment and maintenance of these hierarchies (especially their lower levels), and to the gradual formation and consolidation of a new tradition of visual and verbal designation of deceased persons' social and professional status in Soviet "death places." Such designations became easily readable and detailed "guidebooks" on the hierarchy of Soviet society, indicating the success of Bolshevik instrumentalization of death. 